UDC 323.1:81'246.3(477.52/.6)

DOI https://doi.org/10.32838/2663-5984/2020/4.6

Malyarchuk N.G.

Donetsk State University of Management

\title{
LANGUAGE SITUATION IN THE SOUTH-EAST OF UKRAINE (BASED ON THE MATERIALS OF 1926 ALL-UNION CENSUS)
}

On the basis of data analysis of 1926 All-Union Census, the author has analyzed the composition of the south-eastern population of Ukraine by native language; studied the peculiarities of linguistic structure in particular districts, as well as in towns and villages; carried out comparative analysis of ethnic and linguistic structures of the population; determined the level and character of its language assimilation.

The results of the research enable us to state that in 1926 the Ukrainian language was native for the absolute majority of the population in the south-east of Ukraine. The Russian language was on the second place, it even conceded to Ukrainian in its demographic power, but had more power that is communicative because, in fact, it was the official language in the USSR and it had more assimilation influence. Unlike the Russian-speaking population, dominating in quantity in urban areas, Ukrainianspeaking people concentrated in the rural areas and did not have assimilation potential.

The comparative analysis of ethnic and linguistic structure of the population enables to make conclusion about deformation of language situation in the region. It was more vivid in urban settlements, where the share of Russian-speaking people exceeded the percentage of ethnic Russians a bit more than one and a half times. Although in the rural areas the situation was much less deformed than in the cities, the signs of Russian assimilation were seen there as well. The comparison of correlation between ethnic and linguistic structure of the population in the south-east and across the whole Ukrainian SSR, showed that assimilation processes in south-eastern part of the Republic were happening faster than in the Ukrainian SSR in general.

Having carried out the analysis of language issue in definite regions, the author found out that in the majority of them, except Luhansk, Stalin and Odessa regions, the population, whose native language was Ukrainian, dominated. As far as the urban settlements are concerned, in the majority of districts Russian-speaking community dominated. The largest part of inhabitants, whose native language was Russian, lived in coal-mining Donbass cities - Dmitrivske and Stalin. Concerning rural population of south-eastern Ukraine, the Ukrainian language was native for the majority of population in all the seventeen districts.

Key words: Ukrainian language, Russian language, language assimilation, linguistic structure, ethnic structure, South East of Ukraine, 1926 All-Union census.

The problem statement. The research of language issue in Ukraine in different historical periods is becoming actual nowadays when language factor is actively used both in internal and external politics. In the first place, this concerns the south-eastern Ukraine, which experienced significant Russification. The research of language situation in the region in different historical periods allows to trace the dynamics of changes that took place in the linguistic structure of the population in the region and reproduce the stages of its Russification.

The research source base is the 1926 All-Union census. It enabled to study the language situation in the south-eastern Ukraine even prior to the forced industrialization and solid collectivization, which influenced the ethnodemographic, and language processes in the Ukrainian SSR.
The analysis of recent research and publications. The relevance of the article is stipulated by the fact that the majority of researchers in our country used the 1926 census data for studying social and ethnic structure of Ukrainian SSR population and some of its regions as well $[1 ; 4 ; 7 ; 8 ; 9 ; 12]$, but its informational possibilities were used not fully $[5 ; 6 ; 10$, p. 99].

The purpose of the article: on the basis of 1926 All-Union Census analysis of materials to study the peculiarities of language situation in the south-east of Ukraine in the given period; define peculiarities of linguistic structure of population in the South East of Ukraine in general and in some definite regions, urban and rural settlements; state the demographic power ${ }^{1}$

\footnotetext{
"Term "demographic and communicative power of language", "language stability" was borrowed from: Масенко Л.Т. Мова і суспільство: Постколоніальний вимір. Київ : Вид. дім «КМ Академія», 2004. 163 с.
} 
of the most common languages in the south-east of Ukraine; carry out comparative analysis of ethnic and language structure of the population in a region; define the level and nature of language assimilation of definite ethnic groups; compare the intensity of assimilation processes in region and republic as a whole.

Geographic borders of the research is the territory of south-eastern Ukraine, which includes modern Kharkiv, Luhansk, Donetsk, Dnipropetrovsk, Zaporizhia, Kirovograd, Mykolaiv, Odessa, Kherson regions; in 1926 this territory was divided into 17 districts: Kharkiv, Oziumsk [N.M. In the article the names are given in accordance with census], Kup'iansk, Luhansk, Starobilsk, Artemivsk, Stalin, Mariupol, Melitopol, Zaporizhia, Odessa, Mykolaiv, Kherson, Dnipropetrovsk, Zinoviivsk, Kryvyi Rih, Pershomaysk districts. The following is not included into geographical boundaries: the Crimea, because it wasn't a part of the Ukrainian SSR and Autonomic Republic of Moldova, which wasn't totally ethnic Ukrainian territory, although it was a part of the Ukrainian SSR till 1940.

The author's calculations are based on the data of 12 [2, p. 286-288, 291-293, 309-313] and 13 [3, p. 12-38, 247-256, 340-341, 343-345, 348-349] volumes of All-Union Population Census (1926), which are reflected in the table VI "Population by nationality, native language and literacy", including the information concerning language of population in 17 districts of south-eastern Ukraine in particular, urban and rural settlements as well. Data concerning given figures in the Ukrainian SSR were taken from the issue "Results of Census in Ukraine in brief. 17-12 of December 1926. National and age structure, native language and literacy of population» $[11$, p. 42-45].

\section{Population of UkSSR by native language}

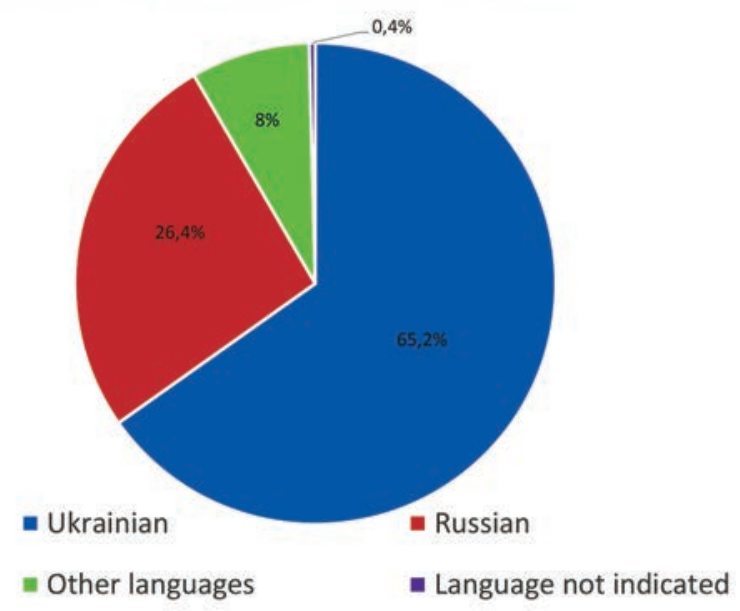

Diagram 1
Presenting the main material. According to the census data, population of the South East of Ukraine constituted 11816147 people. 1926 All-Union Census showed that for absolute majority of population, i.e. for $65.2 \%$ (7701434) Ukrainian was native language; Russian was native for $26.4 \%$ (3124030); other languages were native for $8 \%$ (939250); 0.4\% (51433) didn't declare native language at all (native language was defined as language which the interviewee could speak better or usually spoke). So, by its demographic power Ukrainian language exceeded Russian 2.5 times (see diagram 1 ).

The absolute majority of population with Ukrainian as native language - $90 \%$ (6915521people) lived in villages and only 10\% (785913 people) lived in towns. On the opposite, people with Russian as native language were more equally dispersed between and village: 56\% (1750093 people) lived in cities, 44\% (1373937 people) - in villages.

For comparison, it should be noted that in general in the Ukrainian SSR the Ukrainian language was native for 76,4\% (22160992 people), Russian for $15,2 \%$ (4421813 people), for 8\% (2304250 people) - another languages, $0,4 \%$ (109485 people) didn't answer this question at all (see diagram 2). Thereby, part of the population of south-eastern Ukraine, who had Russian as native language, exceeded the same rate a bit more than 1.5 times.

It should be noted that ethnic and language structure of the population in the south-eastern Ukraine didn't coincide (see diagram 3).

In addition, the correlation between Ukrainian speakers and Russian speakers varied within region and republic as a whole. Thus, in the south-eastern Ukraine share of Ukrainian-speaking population

\section{Population of UkSSR by native language}

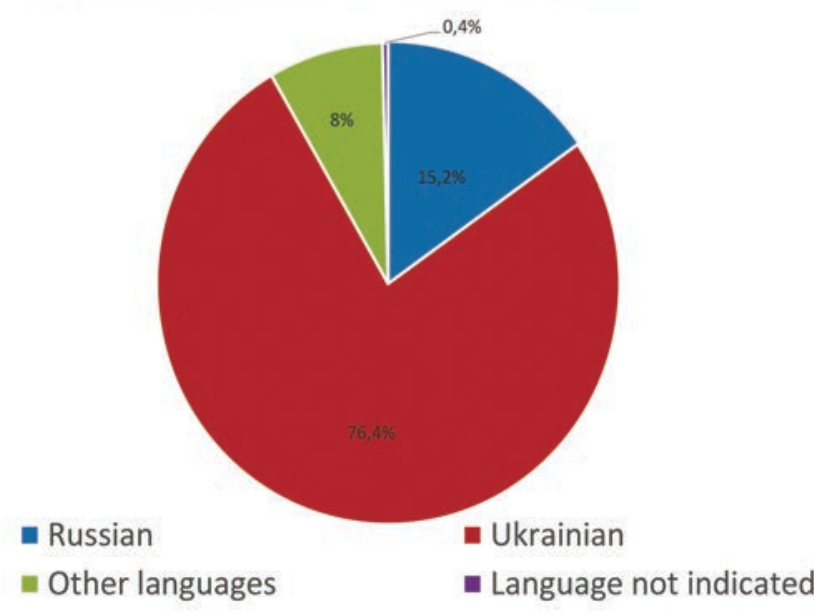

Diagram 2 


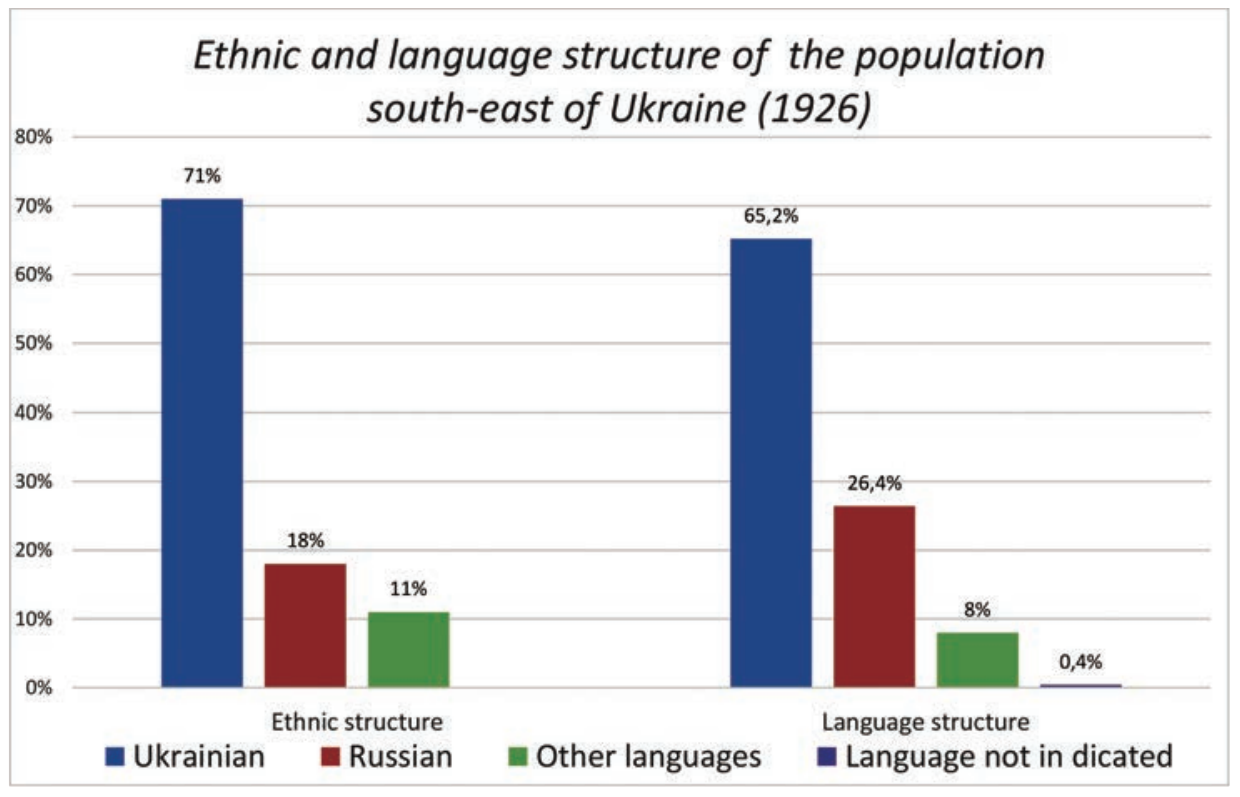

Diagram 3

exceeded the share of Russian-speaking population 2.5 times, whereas in the Ukrainian SSR - it was 5 times. It should be mentioned, that $71 \%$ of Russian-speaking population of Ukraine was concentrated in the south-east.

The share of those who considered Ukrainian as native language was $6 \%$ less than ethnic Ukrainians among the population in the south-eastern Ukraine and constituted $71 \%$. Whereas the proportion of population with Russian, as native language, was $8 \%$ more than the share of ethnic Russians $18 \%$. In addition, the disproportion was obvious between the representatives of other nationalities in the ethnic structure of the region $-11 \%$ and share of those, whose native language was neither Ukrainian nor Russian, but other languages $-8 \%[8$, p. 159$]$.

It should be stated, that there were only $66 \%$ (2054832 people) of ethnic Russians among Russian-speaking population. The other part formed the Ukrainians - 23\% (719944 people) and representatives of national minorities $-11 \%$ (349254), i.e. the majority among those who indicated Russian as native, but were not ethnic Russian, were Ukrainians. Concerned the population with Ukrainian as native language, it should be added, that $99 \%$ (7649632 people) consisted of Ukrainians, the representatives of other nationalities formed only $1 \%$.

The Russians demonstrated the high level of language stability, because $98 \%$ (2054832 people) of them claimed native language of their ethnic background and only 1\% (22985 people) - Ukrain- ian and $0.05 \%$ (1100 people) - other languages. Language stability of the Ukrainians was lower: the Ukrainian language was indicated as native only by $91 \%$ (7649632 people) of native Ukrainians, 8.5\% (719944 people) indicated Russian and $0.2 \%$ (18969 people) - language of other nationalities, 0.2 (15375 people) didn't declare their native language.

In the majority of districts in the South East of Ukraine, precisely in thirteen out of seventeen, the Ukrainian language was native for the majority of population: from $88 \%$ to $51,8 \%$. In Mariupol district Ukrainian was indicated as native by the relative majority of population $-43.8 \%$. As for the Russian language, it was native for the majority of the population only in three districts: Luhansk $-57.5 \%$, Stalin $-46 \%$ and Odessa $-39.1 \%$. In two latest districts this majority was relative, moreover, the difference between Russian speakers and Ukrainian speakers was insignificant, $2 \%$ and $3.5 \%$, accordingly. The share of population, indicating their ethnic languages as native was the highest in Odessa region $-25 \%$ and Mariupol district $-21 \%$, where in the rural area lived representatives of Greek, German, Bulgarian national minorities (see table 1).

So, notwithstanding the domination in quantity of the Ukrainians in the region, their assimilation influence on the representatives of other ethnical minorities was insignificant, moreover, they themselves were the object of assimilation from Russians. This can be explained by the fact that Russians were the titular nation in the USSR, the Russian language was widely used in all the most important spheres of state 
The population of the South East of Ukraine by native language in districts

Table 1

\begin{tabular}{|c|c|c|c|c|c|}
\hline \multirow{2}{*}{ № } & \multirow{2}{*}{ District } & \multicolumn{4}{|c|}{ Native language (\%) } \\
\hline & & Ukrainian & Russian & Other & Not indicated \\
\hline 1 & Starobilsk & 88 & 11.4 & 0.4 & 0.2 \\
\hline 2 & Pershomaysk & 86 & 4 & 9.8 & 0.2 \\
\hline 3 & Kryvyi Rih & 85.4 & 9.3 & 5 & 0.3 \\
\hline 4 & Kup'iansk & 81.5 & 17.9 & 0.2 & 0.4 \\
\hline 5 & Oziumsk & 81 & 17.8 & 0.9 & 0.3 \\
\hline 6 & Zinoviivsk & 79.4 & 14 & 6.3 & 0.3 \\
\hline 7 & Zaporizhia & 78 & 15.4 & 6.3 & 0.3 \\
\hline 8 & Dnipropetrovsk & 77.3 & 18 & 4.3 & 0.4 \\
\hline 9 & Kherson & 68.7 & 22 & 9 & 0.3 \\
\hline 10 & Kharkiv & 65 & 31 & 3 & 1 \\
\hline 11 & Artemivsk & 60 & 34 & 3 & 1 \\
\hline 12 & Melitopol & 52 & 33 & 14.7 & 0.3 \\
\hline 13 & Mykolaiv & 51.8 & 33 & 15 & 0.2 \\
\hline 14 & Stalin & 44 & 46 & 9 & 1 \\
\hline 15 & Mariupol & 43.8 & 34.9 & 21 & 0.3 \\
\hline 16 & Luhansk & 38 & 57.5 & 3.5 & 1 \\
\hline 17 & Odessa & 35.6 & 39.1 & 25 & 0.3 \\
\hline & Totally & 65.2 & 26.4 & 8 & 0.4 \\
\hline
\end{tabular}

and social life (even during the period of Ukrainization) and, therefore, had more communicative potential than Ukrainian.

It should be noted, that in all the south-eastern districts, as well as in the region in general, divergence between native language and ethnic background of the part of population was observed. The most obvious it was in Odessa and Mariupol districts, where the share of population with native Russian language was $16 \%$ higher than those whose nationality was Russian (39.1\% and 23.3\%, 34.9\% and 19\% accordingly). In Luhansk and Stalin district this rate was $15 \%$ (57.5\% of population with Russian language as native and $43 \%$ of ethnic Russians) and $12 \%$ (46\% of population with Russian language as native and $34.3 \%$ of ethnic Russians).

In those districts where population lived mainly in small towns and in villages, the deformation of language situation was insignificant. For example, in Pershomaysk district the share of Russian-speakers was $4 \%$, only $1 \%$ exceeded the share of ethnic Russian population - 3\%. In Starobilsk district this rate constituted $1.4 \% \quad(11.4 \%$ Russian-speaking and $10 \%$ of ethnic Russians), in Kup'iansk $-2.1 \%$ (17.9\% Russian-speaking and $15.8 \%$ of ethnic Russians), Oziumsk - 3\% (17.8\% of Russian-speaking and $15 \%$ of ethnic Russians). However, even in these, mainly Ukrainian according to their ethnic structure districts, the signs of Russian-language assimilation were present.
The linguistic structure analysis of urban population in south-eastern Ukraine showed that the share of those who considered Russian as native language made up 61\% (1750093 people), Ukrainian - 27\% (785913 people), other languages - 11\% (330989 people), 1\% (22269 people) didn't declare native language at all (see diagram 4 ).

It should be noted, that among urban population of the Ukrainian SSR Russian-speaking people constituted the majority, not absolute but relative one. Their share was 44\% (2386638 people), whereas the share of Ukrainian-speaking constituted 36\% (1930620 people), those who chose other languages - 19\% (1004103 people), 1\% (37879 people) did not declare native language at all (see diagram 5).

The towns of the south-eastern of Ukraine were the centres of Russian language assimilation, significant divergence between language and nationality of the inhabitants proves it (see diagram 6). Thus, the share of Ukrainians among urban population of this macroregion equaled to $42 \%$ in 1926 , whereas the Ukrainian language was considered as native only by $27 \%$ from the total.

However, $61 \%$ of population considered Russian language as native, notwithstanding the fact that the share of Russians in towns made up 36\%. The great majority of representatives of other nationalities $-22 \%$ exceeded twice the share of town inhabitants who spoke other languages $-11 \%$ [8, p. 160]. 


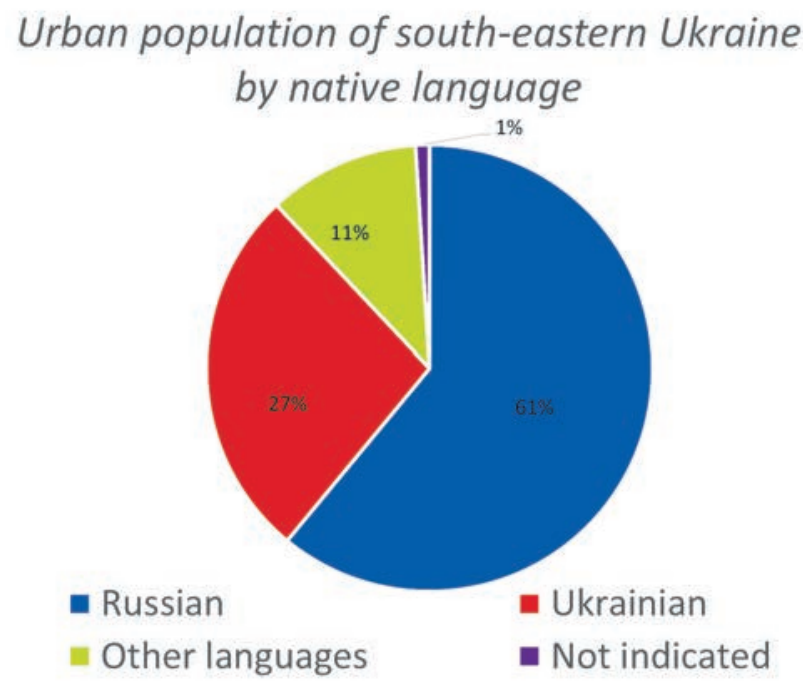

Diagram 4
Urban population of UKSSR by native language

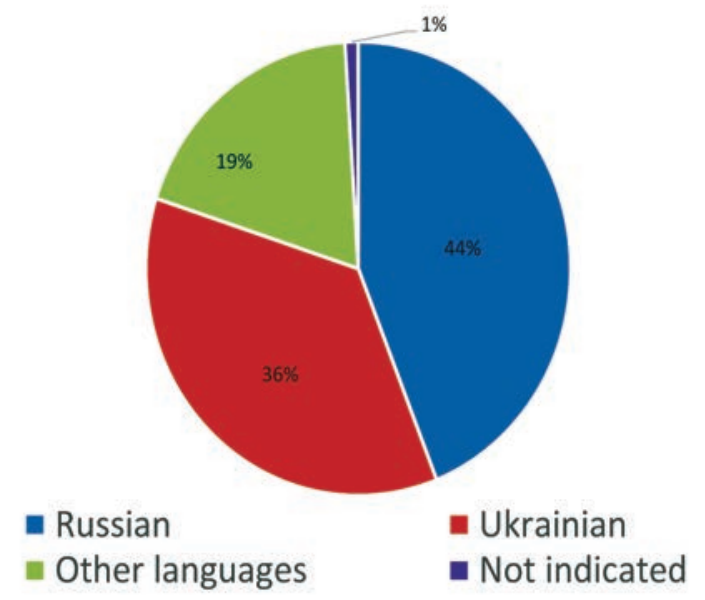

Diagram 5

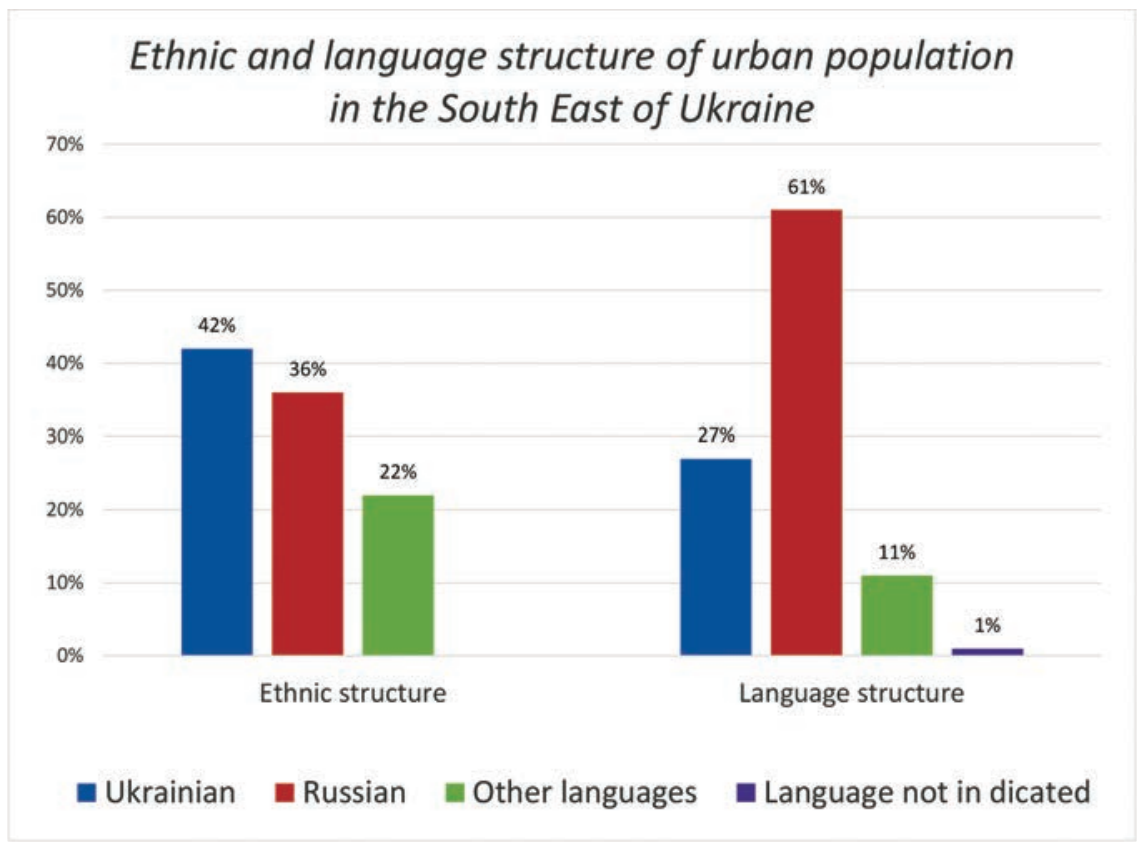

Diagram 6

Having analyzed the language structure of urban population in certain districts of the south-eastern Ukraine, we found out that in twelve out of seventeen districts the majority was population with Russian as native language. In ten districts: Mariupol (82.6\%), Stalin (80\%), Luhansk (73.3 \%), Melitopol (72\%), Mykolaiv (70\%), Odessa (65\%), Artemivsk (62\%), Kherson (59\%), Dnipropetrovsk (57\%), Kharkiv (53\%) people whose native language was Russian formed the absolute majority, and in two: Oziumsk (49.2\%) and Zaporizhia (48\%) - relative majority. As we can see, especially high was the share of Russian-speaking population in three Donbass districts: Mariupol, Stalin and Luhansk. Ukrainian-speakers formed the majority in five districts: Starobilsk (63.9\%), Kup'iansk (63\%) and Kryvyi Rih (62\%) - absolute, in Zinoviivsk (48\%) and Pershomaysk (45\%) - relative majority. Towns in these districts (except Zinoviivsk) had population not exceeding 50000 people, these towns were not large industrial and trade centres, that's why the Russians formed insignificant part of population there, thus the assimilation processes took place slower.

As it is shown in Table 3, in towns of south- eastern Ukraine the share of population with Russian as native language was the highest in Dmitrivske (85\%) and Stalin $(81 \%)$, coal-mining towns in the east of Ukraine, which were territorially nearer to Russian SFSR, with 
Історія України

Table 2

Urban population of southern east of Ukraine by native language in districts

\begin{tabular}{|c|c|c|c|c|c|}
\hline \multirow{2}{*}{ № } & \multirow{2}{*}{ District } & \multicolumn{4}{|c|}{ Native language (\%) } \\
\hline & & Ukrainian & Russian & Other & Not indicated \\
\hline 1 & Starobilsk & 63.9 & 34.7 & 1.3 & 0.1 \\
\hline 2 & Kup'iansk & 63 & 35 & 1 & 1 \\
\hline 3 & Kryvyi Rih & 62 & 30 & 8 & 1 \\
\hline 4 & Oziumsk & 48.4 & 49.2 & 2 & 0.4 \\
\hline 5 & Zinoviivsk & 48 & 35 & 16 & 1 \\
\hline 6 & Pershomaysk & 45 & 14 & 40 & 1 \\
\hline 7 & Zaporizhia & 39 & 48 & 12 & 1 \\
\hline 8 & Kharkiv & 38 & 53 & 8 & 1 \\
\hline 9 & Artemivsk & 31 & 62 & 6 & 1 \\
\hline 10 & Dnipropetrovsk & 29 & 57 & 13 & 1 \\
\hline 11 & Kherson & 26 & 59 & 14 & 1 \\
\hline 12 & Luhansk & 20.5 & 73.3 & 5.1 & 1.1 \\
\hline 13 & Melitopol & 17 & 72 & 10 & 1 \\
\hline 14 & Mykolaiv & 17 & 70 & 13 & 1 \\
\hline 15 & Stalin & 14 & 80 & 5 & 1 \\
\hline 16 & Mariupol & 10 & 82.6 & 7 & 0.4 \\
\hline 17 & Odessa & 11 & 65 & 23.7 & 0.3 \\
\hline & Totally & 27 & 61 & 11 & 1 \\
\hline
\end{tabular}

Table 3

Population of the biggest towns in the South East of Ukraine by native language

\begin{tabular}{|c|c|c|c|c|c|}
\hline \multirow{2}{*}{$№$} & \multirow{2}{*}{ City } & \multicolumn{4}{|c|}{ Native language (\%) } \\
\cline { 2 - 6 } & Dussian & Ukrainian & other & Not indicated \\
\hline 1 & Stalin & 85 & 10 & 4 & 7 \\
\hline 2 & Mykolaiv & 81 & 11 & 11 & 1 \\
\hline 3 & Luhansk & 78 & 10 & 6 & 1 \\
\hline 4 & Kherson & 66.4 & 16.3 & 16.2 & 1 \\
\hline 5 & Odessa & 66.1 & 10.1 & 23.5 & 1.2 \\
\hline 6 & Kharkiv & 64 & 24 & 11 & 0.3 \\
\hline 7 & Dnipropetrovsk & 64 & 20 & 15 & 1 \\
\hline 8 & Zinoviivsk & 54 & 26 & 19 & 1 \\
\hline 9 & Zaporizhia & 52 & 34 & 13.5 & 1 \\
\hline 10 & Totally & 67 & 17 & 15 & 0.5 \\
\hline
\end{tabular}

significant number of the Russians in the ethnic structure of urban population: $64 \%$ and $57 \%$ accordingly. As it can be seen, the share of Russian-speaking population exceeded the share of Russian ethnic population nearly by one fourth: in Dmitrivsk by $21 \%$, in Stalin by $24 \%$. In the majority of other big towns of the South East the language situation was even more deformed, because divergence between share of ethnic Russians and those, who indicated Russian as native, varied between $33 \%-27 \%$ (in Mykolaiv it constituted 33\%, Luhansk $32 \%$, Dnipropetrovsk - 32\%, Kharkiv - 29.1\%, Kherson $-28 \%$, Odessa $-27.4 \%$, Zinoviivsk $-27 \%$ ).

In south-eastern Ukraine, as in the Republic in general, the Ukrainian language was much more common in villages than in towns. Hence, among rural inhabitants of the region $77.4 \%$ (6915521 people) indicated Ukrainian as native, $15.3 \%$ (1373937 people) - Russian, 7\% (608261 people) - other languages, 0.4 (29164 people) didn't declare native language (see diagram 7).

But even in villages the share of Ukrainian speakers in the south-eastern Ukraine was less than in the Ukrainian SSR on the whole and, consequently, the share of Russian speakers was higher (see diagram 7 and 8). Thus, Ukrainian-speaking people made up $85.6 \%$ (20230372) of rural population of the republic, Russian-speaking made up 8.6\% (2035175), those who chose another languages - $5.5 \%$ (1300147), $0.4 \%$ (71606) didn't declare native language.

As it is seen from diagram 9, share of the Ukrainians among rural population constituted $80 \%$ and Ukrainian 
Rural population of south-eastern Ukraine by native language

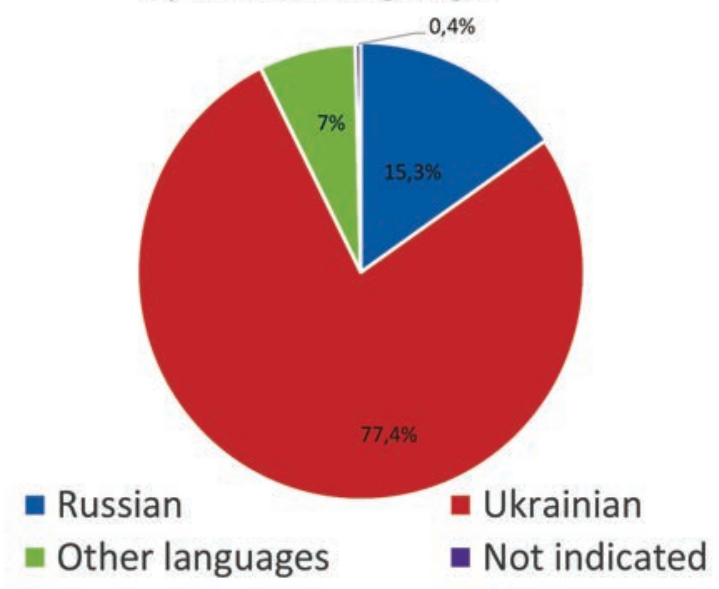

Diagram 7

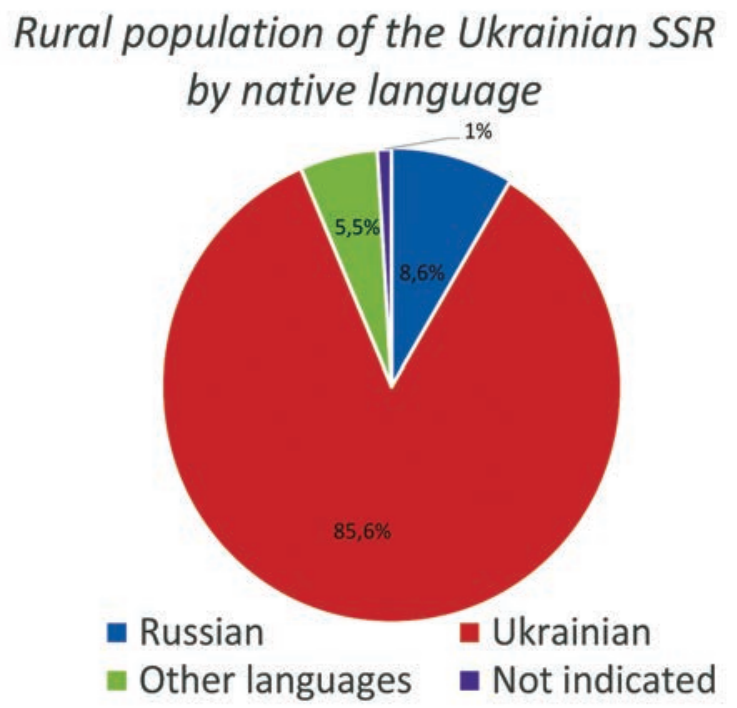

Diagram 8

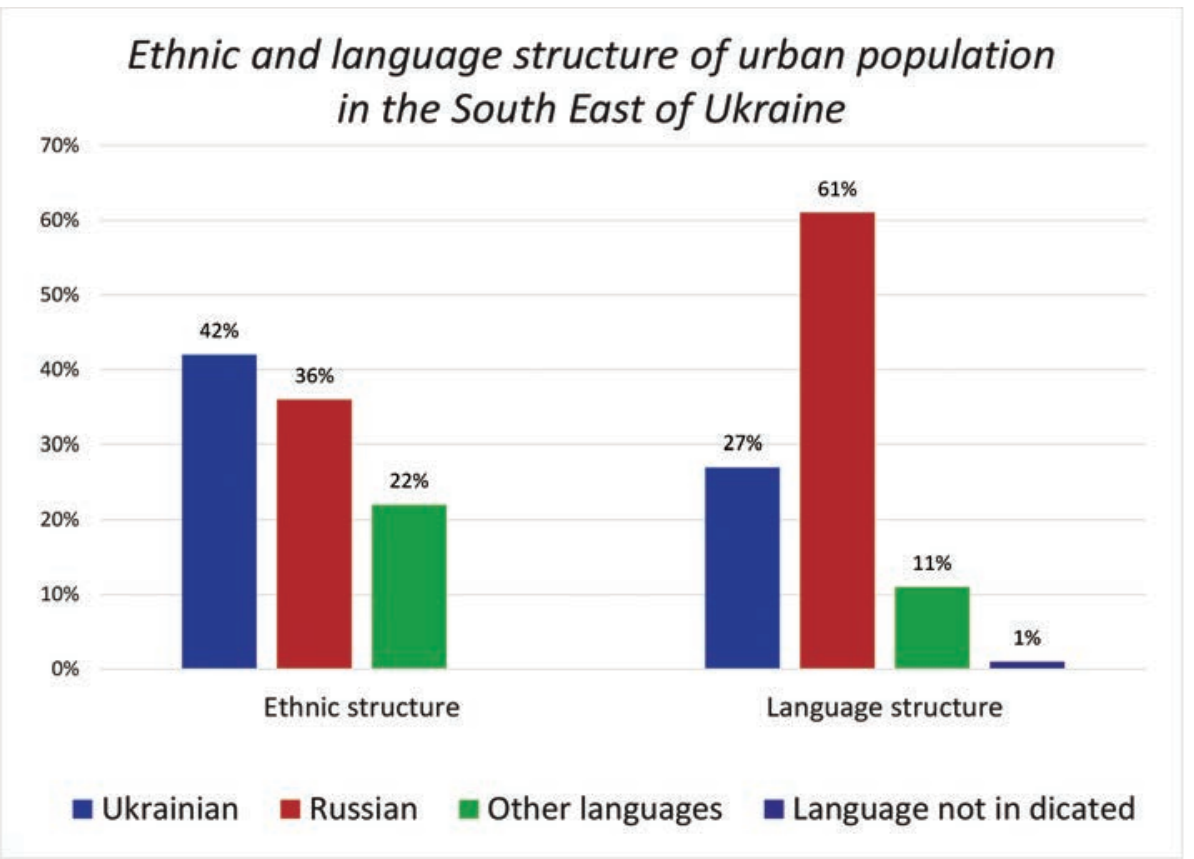

Diagram 9

language was recognized as native only by $77.4 \%$ from total number. The level of assimilation was insignificant among other nationalities, total share of which equaled to $8 \%$, whereas the share of those who recognized other languages as native equaled to $7 \%$ [8, p. 163]. However, the Russian language was considered as native by $15.3 \%$ of population, notwithstanding that share of the Russians among rural population equaled to $12 \% .0 .3 \%$ of rural inhabitants didn't declare native language.

Language situation in the villages was not so deformed as in the urban areas, because diver- gence between native language and nationality was less significant.

In all the Ukrainian south-eastern districts the majority of rural population considered Ukrainian as native language. This rate was the highest in Dnipropetrovsk district $-94 \%$ from the total, and the lowest in Luhansk district, where population with Ukrainian as native language formed the relative majority $49 \%$. It should be added, that in this particular district the share of rural population with Russian native language was the highest in all the south-eastern dis- 
tricts and constituted 47\%. In other districts it fluctuated from 3\% (in Pershomaysk district) to $29.7 \%$ in Melitopol district. As for population with other native languages, their highest share was in multinational districts Odessa - 26\% and Mariupol - 25.3\% from total (see table 4).

Conclusions. Thus, analysis of 1926 All-Union population census showed that when at the time of its conduction, the most widespread languages in south-eastern Ukraine were Ukrainian and Russian. Notwithstanding the fact that demographic power of the Ukrainian language exceeded Russian 2.5 times, the latest in particular had assimilation influence both on people of other ethnic background and on the representatives of Ukrainian titular nation. Language deformation is seen from the fact that the share of Russian speakers exceeded approximately 1.5 times the share of ethnic Russians in the region. The Russians were distinguished by high language stability, because only $1.05 \%$ of Russians declared as native not Russian language. Among the population with Russian language as native Russians made up a bit more than a half, the others were representatives of other ethnic background, including the most numerous- Ukrainian, whereas the share of non-Ukrainians among Ukrainian-speaking community of the region was insignificant. This also reflects the fact that despite significant demographic power, the Ukrainian language had little assimilation potential, conceding to Russian. Moreover, the Ukrainians themselves were the object of assimilation and had lower language stability than Russians. Such assimilation influence can't be considered as natural process, because in south-east of Ukraine there were four times less ethnic Russians than Ukrainians.

In urban settlements population with Russian as native made up the absolute majority, while in rural areas, on the contrary, Ukrainian-speaking population prevailed. Though language situation in villages was less deformed than in towns, the signs of Russian assimilation influence were also evident there, because the share of ethnic Russians was lower than those who declared Russian as native.

Having analyzed the linguistic structure of the population of specific districts in south-eastern Ukraine, we concluded that population with Ukrainian as native predominated in the majority of them. The exception were Lugansk district, where absolute majority was Russian-speaking population, and Stalin and Odessa regions, where it was relative majority.

Concerning urban settlements, only in seven out of seventeen districts the majority formed population with Ukrainian as native, Russian-speaking community dominated in quantity in the other twelve districts. The largest share of inhabitants with Russian as native was in Dmitrivske and Stalin. In these coal-mining towns, the absolute majority of population were Russians- migrants from Russian prov-

Table 4

Rural population of south-eastern Ukraine in districts by native language

\begin{tabular}{|c|c|c|c|c|c|}
\hline \multirow{2}{*}{ № } & \multirow{2}{*}{ District } & \multicolumn{4}{|c|}{ Native language (\%) } \\
\cline { 3 - 6 } & & Ukrainian & Russian & Other & Not indicated \\
\hline 1 & Dnipropetrovsk & 94 & 4.8 & 1 & 0.2 \\
\hline 2 & Starobilsk & 89 & 10.5 & 0.3 & 0.2 \\
\hline 3 & Kryvyi Rih & 89 & 6.2 & 4.5 & 0.3 \\
\hline 4 & Pershomaysk & 89 & 3 & 7.8 & 0.2 \\
\hline 5 & Zinoviivsk & 85.4 & 10 & 4.3 & 0.3 \\
\hline 6 & Zaporizhia & 83 & 11 & 5.5 & 0.5 \\
\hline 7 & Kup'iansk & 82.3 & 17.2 & 0.2 & 0.3 \\
\hline 8 & Oziumsk & 82 & 16.7 & 1 & 0.3 \\
\hline 9 & Artemivsk & 81 & 14 & 4 & 1 \\
\hline 10 & Kharkiv & 80.5 & 19.1 & 0.2 & 0.2 \\
\hline 11 & Kherson & 77 & 15.4 & 7.5 & 0.1 \\
\hline 12 & Stalin & 67.3 & 19.4 & 12.3 & 1 \\
\hline 13 & Mykolaiv & 65 & 19.8 & 15 & 0.2 \\
\hline 14 & Odessa & 60.6 & 13 & 26 & 0.4 \\
\hline 15 & Melitopol & 55 & 29.7 & 15 & 0.3 \\
\hline 16 & Mariupol & 53.3 & 21 & 25.3 & 0.4 \\
\hline 17 & Luhansk & 49 & 47 & 3 & 1 \\
\hline & Totally & 77.4 & 15.3 & 7 & 0.3 \\
\hline
\end{tabular}


inces, who came here to find work in coal-mines, that's why the divergence between their ethnic background and native language was less than in other big towns of the region.

Concerning rural population of South East of Ukraine, Ukrainian was native for absolute majority in nearly all the districts. The exception was Luhansk district, where relative majority of population declared the Ukrainian language as native.

The assimilation processes in south-eastern Ukraine occurred faster than across the whole Republic. The share of Russian-speaking population among inhabitants of this region exceeded the same rate in the Ukrainian SSR a bit more than 1,5 times and the share of Ukrainian-speaking population only 2.5 times exceeded the share of Russian speakers, whereas in the Ukrainian SSR in general this figure was five times more. In towns of south-eastern Ukraine the Russians constituted the absolute majority while across the whole Republic they constituted the relative one. Even in villages, the share of Ukrainian-speaking population was less than in the Ukrainian SSR in general and, consequently, the share of Russian-speaking population was larger.

\section{References:}

1. Воронко О.Г. Розвиток етнодемографічних процесів і формуваня соціальної структури суспільства в Україні 20-х рр. ХХ ст. : дис. ... канд. іст. наук : 07.00.05. Київ, 1998. 230 с.

2. Всесоюзная перепись населения 1926 года : Украинская Социалистическая Советская Республика. Правобережный подрайон. Левобережный подрайон. Народность. Родной язык. Возраст. Грамотность. Т. 12. Отд. 1. Москва : Издание ЦСУ Союза ССР, 1928. 482 с.

3. Всесоюзний перепис людності 1926 р. : Українська соціялістична радянська республіка. Степ. Дніпрянський промисловий підрайон. Гірничий підрайон. Національність, рідна мова, вік, письменність. Т. ХІІІ. Від. 1. Москва : Видання ЦСУ Союзу РСР, 1929. 465 с.

4. Гринь Д. Зміни в національному складі міського населення України у 20-30-х рр. XX ст. Україна на порозі XXI століття: актуальні питання історії : збірник наукових праць. Київ : Стилос, 1999. С. 196-202.

5. Малярчук Н.Г. Мовна структура населення Східної України (за матеріалами Всесоюзного перепису населення 1926 року). Нові сторінки історії Донбасу : збірник статей. Вінниця : ДонНУ ім. Василя Стуса, 2018. Кн. 27. С. 61-73.

6. Малярчук Н.Г. Мовна структура населення південної України (за матеріалами Всесоюзного перепису населення 1926 року). Історичні і політологічні дослідження. 2019. № 2 (65). С. 58-71.

7. Малярчук Н.Г. Російське населення Східної України (за матеріалами Всесоюзного перепису населення 1926 року). Історичні і політологічні дослідження. 2017. № 1 (60). С. 36-44.

8. Малярчук Н.Г. Росіяни в етнічній структурі населення південно-східної України (за матеріалами Всесоюзного перепису населення 1926 року). Нові сторінки історії Донбасу : збірник статей. Вінниця : ДонНУ імені Василя Стуса, 2017. Кн. 26. С. 155-167.

9. Малярчук Н.Г. Українське та російське населення південної України: кількісний аспект (за матеріалами всесоюзного перепису населення 1926 року). Science progress in European countries: new concepts and modern solutions : Papers of the 9th International Scientific Conference. September 6, 2019, Stuttgart, Germany. P. 229-236.

10. Романцов В.О. Українці на одвічних землях (XVIII - поч. XXI ст.). Ктї : Видавництво ім. Олени Теліги, 2004. 183 с.

11. Статистика України. № 124. Серія I «Демографія». Короткі підсумки перепису населення України. 17- 12 грудня 1926 р. Національний і віковий склад, рідна мова та писемність населення. Харків, 1928. 210 с. Т. V. Вип. 2. Х с.

12. Турченко Г.Ф., Овчаренко Г.Ф. Етнічний склад міського населення Півдня України (за матеріалами Всесоюзного перепису населення 1926 р.). Наукові праці історичного факультету Запорізького національного університету. 2009. Вип. XXVII. С. 185-192.

\section{МалЯРчУК Н.Г. МОВНА СИТУАЦІЯ НА ПІВДЕННОМУ СХОДІ УКРАЇНИ (ЗА МАТЕРІАЛАМИ ВСЕСОЮЗНОГО ПЕРЕПИСУ 1926 Р.)}

На основі аналізу даних Всесоюзного перепису населення 1926 р. автором проаналізовано склад населення Південно-Східної України за рідною мовою, розглянуто особливості мовної структури по окремих округах, а також міських і сільських поселеннях регіону, здійснено порівняльний аналіз етнічної та мовної структур населення, визначено рівень і характер його мовної асиміляиії.

Результати дослідження дають змогу стверджувати, щзо в 1926 рочі українська мова була рідною для абсолютної більшості населення південного сходу України. На другому місиі була російська мова, яка хоча й поступалася украӥнській за своєю демографічною потужсністю, проте мала значно більшу 
потужність комунікаційну, оскільки фактично була державною мовою в СРСР, а отже, мала більший асиміляиійний вплив. На відміну від російськомовного населення, яке кількісно домінувало в міських поселеннях, україномовне зосереджувалося в сільській місцевості й не мало асиміляційного потенціалу.

Порівняльний аналіз етнічної та мовної структури населення дав змогу зробити висновок про деформованість мовної ситуаиії в регіоні. Найбільш яскраво вона проявлялася в міських поселеннях, де частка російськомовних трохи більш як у півтора раза перевищувала відсоток етнічних росіян. Хоча в селах мовна ситуація була значно менш деформованою, ніж у містах, усе ж таки ознаки російського асимілящійного впливу були наявні й там. Порівняння співвідношення етнічної та мовної структури населення на південному сході й загалом по УСРР показало, що асиміляиійні проиеси в південно-східній частині республіки відбувалися швидше, ніж загалом по УСРР.

Здійснивши аналіз мовної ситуаиії в окремих округах, автор з'ясувала, що в більшості з них, крім Луганської, Сталінської та Одеської, переважало населення з рідною українською мовою. Щодо міських поселень, то в більшості округ кількісно домінувала російськомовна спільнота. Найбільшою частка мешканиів з рідною російською мовою була в шахтарських містах Донбасу - Дмитрівському i Сталіні. Щодо сільського населення Південно-Східної України, то украӥнська мова була рідною для більшості населення в усіх сімнадияти округах.

Ключові слова: українська мова, російська мова, мовна асимілячія, мовна структура, етнічна структура, південний схід Украӥни, Всесоюзний перепис населення 1926 року. 